\title{
Critical Literacy: A Universal Tool to Empower English Teachers and Learners
}

\author{
Adaninggar Septi Subekti \\ Universitas Kristen Duta Wacana, Yogyakarta, Indonesia \\ Email: adaninggar@staff.ukdw.ac.id
}

\begin{abstract}
Language teachers should not only facilitate learners to learn the language but also facilitate them to realize that every day's discourses, including language and education, are socially constructed. This is where critical literacy (CL) plays its role as a frame through which teachers can actively and autonomously participate in the world around them and facilitate learners to be able to do so through learning instructions. CL functions as a universal tool, like bricoleur, one can use to see numerous social phenomena from a critical stance. It is a different way, lens, or teaching framework, believing that one should question every day's discourses instead of just accepting them as they are, with the ultimate goal of promoting social justice. Hence, this paper explains the importance of CL in empowering both teachers and learners, how it works to serve this purpose, and some practical strategies of its implementation in a language class.
\end{abstract}

Keywords: Critical literacy, discourses, practical strategies

\section{Introduction}

The role of teachers in students' learning is undoubtedly very important. Teachers are often thought to be in the position of influencing what learners learn and to some extent how they learn it (Richards \& Rodgers, 2014). Specific to the English as second language (L2) learning context, teachers' role was very central back in the earlier days when English learning was highly centralised before the introduction of communicative language teaching in the early 1980s (Richards \& Rodgers, 2014). As communicative teaching becomes more and more popular, teachers' role seems to be less central as students are given more responsibility for their own learning. However, the seemingly less central role of teachers does not necessarily mean teachers' role becomes less important. On the contrary, it becomes even more important as teachers take the role of facilitators providing activities and environments supporting learners' learning (Johnson, 1994).

\section{Definition of Critical Literacy}

In the educational field, the word 'literacy' is not a new concept. It may refer to knowledge about a particular subject, for example 'computer literacy,' which means the knowledge in using computers. In general terms, it is often described as the ability to read and write. However, "what exactly does the ability to read, for example, entails?" (Janks, 2010, p. 2). Many high school students may have been familiar with the Cinderella story. They may have heard of it when they were younger or they may have read the story at school. They may have been familiar with comprehension questions about 
the story, which necessitate them to skim and scan the text. But, have teachers ever asked the students why Cinderella is pictured as a slender and attractive young lady whilst her stepsisters are not? Have teachers ever asked students why the prince is pictured as a handsome and tall young man? What is more, have teachers ever asked students if they have ever imagined Cinderella as an Asian or African lady instead of a Caucasian or European lady? Such questions are explored deeper in Critical Literacy (CL).

CL should be distinguished from critical thinking (Janks, 2017). Whilst critical thinking needs analysis based on reasons, CL "is an ability to 'read' the world to understand how power works to include and exclude and to privilege some at the expense of others" (p. 132). CL originates from the seminal work of Paulo Freire in Brazil (see Freire, 1972). He showed how adult literacy learners learn to read both the word and the world critically and how this practice helps them realize that the world is socially constructed and they can take a role as agents of change for a better world. Hence the term "texts" in CL framework is not limited to textual products such as literary works, reading passages, or other written documents, but it also includes every discourse in every day's life such as television ads, news, movies, dramas, speeches, customs, and traditions (Janks, 2010). Hence, there is no such thing as CL texts. Rather, the world as text can be analyzed or read using the CL framework.
Janks (2017) stated that "at the center of current approaches to critical literacy is an understanding of how power works through discourses, and through their manifestations in texts" (p. 135). It means CL tries to interrogate the role of power in discourses and its manifestations in various texts around us. Janks (2017) further explained that texts and practices are positioned by the authors and in turn, these two work to position readers. In other words, it believes that texts are never neutral (Janks et al., 2014) as they always carry the interest of people in power (the author, for example) at the expense of others (Janks, 2010). For example, the Cinderella story previously mentioned may position readers to have an idea that having a slender body like Cinderella's is desirable. It may also position readers to think that a dream man should be like the prince, being handsome, tall, and rich. It means those not in possession of these characteristics are marginalized by the story. In such cases, a CL education enables teachers and learners to interrogate this positioning to know whose interests certain texts serve. Once this is done, they should decide whether to support the position of the author of the texts or to go against it. In the Discussion section, the roles of CL to empower both teachers and learners as well as practical strategies of its implementation in English class are further explained. 


\section{Discussion}

\subsection{Consequences of teaching English, a dominant language}

Despite their important role, perhaps only a few English teachers realize that becoming English teachers does not only carry the responsibility of teaching students English but also teaching them the world around them. For a simple example, to teach English also means to teach a dominant language spoken by millions of people as the introductory language of politics, trade, and education.

To teach a dominant language such as English is not easy as it carries dual and dilemmatic consequences related to access called 'access paradox' (Janks, 2004). Janks (2004) stated that English is a powerful world language and access to English gives learners what is called 'linguistic capital.' In relation to the linguistic market theory proposed by Bourdieu (see Bourdieu, 1991), teachers of powerful languages, among which English may be one of the most powerful, consequently have more responsibilities. Teachers who take issues of language in relation to power and identity seriously should confront some paradoxes in their profession (Janks, 2004). If teachers provide students with the dominant variety of the dominant language, teachers help support and increase its dominance (Janks, 2004). For example, teachers who continuously emphasize the use of "Standard Englishes", very often British and American Englishes, in teaching, may contribute to the dominance of these varieties as the benchmarks of learners' considering their English being right or wrong, and good or bad. If teachers deny students access, on the other hand, they may indirectly help marginalize learners in a community that continues to acknowledge the language as a mark of distinction (Luk \& Lin, 2006). What is more, denying students access to dominant language may also mean denying them access to the extensive resources which are available in that language (Janks, 2004). To put it simply, there is a consequence for English teachers to understand that access to English is not a simple matter, and to realize the impacts of the widespread use of English across the world and the ways in which English hinders people from learning other languages (Janks, 2004).

To facilitate learners to realize social phenomena, teachers in the first place need to be aware that the phenomena exist and be able to investigate why they happen, how they happen, who are an advantage because they happen, and who are in disadvantage because they happen (McLaughlin \& DeVoogd, 2004b). This is where CL plays a role in equipping teachers with the ability to interrogate social phenomena around them and facilitate learners to be able to do so through learning instruction.

\subsection{The roles of Critical Literacy for teachers}

$C L$ education aims at equipping ones with "a language of critique", to analyze and challenge dominant ideology and social 
assumptions which are manifested in cultural texts and "a language of possibility" to rewrite these cultural texts in a way which could accommodate the voices silenced in the original texts to be present or to be present more equally (Lau, 2013, p. 2). Janks (2010) argued that CL is needed even in a seemingly peaceful world where more and more people can access healthcare and education and can achieve their dreams. There are many differences around us and in a place that is rich with differences, there may still be fear and intolerance. As the difference is structured in relation to power, privilege, and marginalization are still likely to happen due to unequal access to resources based on language, gender, race, ethnicity, religions, and many others. Janks (2010) further encourages people to manage their daily life's politics, which she described as "little p politics," as opposed to "big $\mathrm{P}$ politics", which concerns political parties, legislation, general elections, and the likes. Little p politics, she described, is about the micro-politics of one's everyday life (Janks, 2010). It is about how one treats others, how ones teach, how ones see social phenomena, and many others.

Vasquez (2004) pointed out that teachers have to know what CL is and to experience it themselves and to know how these practices can influence their students before these students feel safe to practice them on their own. Here CL plays its role as a frame through which teachers can actively and autonomously participate in the world around them (Janks, 2010; Vasquez, 2004, 2010) and helps learners to be able to do so as well through learning instructions in class. CL can function as a universal tool, like bricoleur, that one can use to see numerous social phenomena around them from a critical stance (Janks, 2010). In other words, it is a way, lens, or framework of teaching, which believes that one should question the world or discourses around them instead of just accepting them as they are, with the ultimate goal of promoting social justice (McLaughlin \& DeVoogd, 2004b; Vasquez, 2010). It focuses on power issues based on which ones can do reflection and transformation, which may result in taking an action to remedy the injustice manifested in texts or discourses around them (McLaughlin \& DeVoogd, 2004b). In this respect, teachers can help learners learn to question texts in ways developing their critical reading practices, instead of just accepting these texts as they are (Comber, 2001). Here, teachers play crucial social agents who are capable of transforming social practices through facilitating learners in deconstructing hidden messages and discriminatory practices manifested texts to create a better society.

\subsection{Teachers' role in creating learning environment that promotes a critical stance}

Teachers' role in introducing and developing CL is complex. The first and foremost is teachers should have a personal understanding of CL. 
Freire and Shor (1987) reminded that when using CL as a framework of teaching, teachers also need to challenge dominant ideologies around them rather than simply accepting them as destiny. Only then, teachers can teach students about it by modelling reading from a critical stance in the day to day teaching and giving access to various texts through which students can read from a critical stance (McLaughlin \& DeVoogd, 2004b). McLaughlin and DeVoogd (2004) stated that just to become critical is not enough. Rather, it is a process that requires learning and changing over time. Teachers should be engaged in self-critical practices and should always remain open to possibilities. Simply put, “teacher's role in helping students to become critically aware actually begins with a personal understanding of engagement in critical literacy" (McLaughlin \& DeVoogd, 2004, p. 55). Once teachers have been critically aware, to teach students from a critical stance will be a natural process (McLaughlin \& DeVoogd, 2004b). The first step is, just like any other reading activity, teachers should make sure that learners have sufficient background knowledge which enables them to read from a critical stance. Scaffolding may be necessary in the process. Here, teachers can explain, give some demonstrations and guidance, and facilitate learners to practice and reflect. From these steps, there will be a gradual transfer of responsibility from the teachers to learners to further understand the texts in a critical stance (McLaughlin
\& DeVoogd, 2004b). The reflection process often results in learners' making connections, "text to self, text to text, text to the world" (McLaughlin \& DeVoogd, 2004, p. 56), which can eventually promote their ability to apply what they have obtained when they are reading other texts.

\subsection{Critical Literacy practices in L2 classrooms}

Janks (2010) reminded that doing CL in language classrooms can be serious and playful. Teachers, in this regard, play a vital role in engaging learners in CL. Various texts like pictures, ads, speeches, and movies can be used to engage learners in CL practices (Vasquez, 2010). The level of difficulty of texts can be adjusted to learners' level and proficiency as introducing CL in class should be done step by step with appropriate sequence of tasks and strategies (Crookes, 2013). Hence, it is necessary to scaffold learners during the discussion through delivery which is easy to understand. In this regard, there are various strategies that teachers can use to engage students in CL practices. Among them are problem posing and the making of alternative texts (McLaughlin \& DeVoogd, 2004b).

The first strategy is problem posing. This is usually the first step in introducing critical literacy to students who have not known it previously. Using this strategy, teachers facilitate learners to question the author's hidden messages from a critical stance (McLaughlin \& DeVoogd, 2004a). There are some sets 
of questions that can be used to engage students to critically investigate texts using CL. The questions invite readers to investigate how the texts try to position readers and to think of who the privileged voices and the silenced voices are respectively (Bean \& Moni, 2003). The following questions can be used (McLaughlin \& DeVoogd, 2004a, p. 41)

1. Who is in the text/picture/situation? Who is missing/not in the picture?

2. Whose voices are represented?

3. Whose voices are marginalised or discounted? Why may disagree with the text?

4. What are the intentions of the author? What does the author want the reader to think?

This set of questions can be assigned in group discussions, the result of which can be shared in jigsaw learning in which each student will need to change the groups and become the representative of the former groups to share the results of their discussions. During the group discussions, teachers may need to walk around and be engaged in some of their discussions to scaffold students in case they need help.

The second strategy that can be used is to make alternative texts, which Bean and Moni (2003) referred to as 'to counter text.' This strategy can be used as the continuation of the first strategy which focuses more on investigating the hidden meaning behind texts. In comparison, in this second strategy, learners basically are invited to answer the question 'how might we rewrite the text to deal with the silences?' (Bean \& Moni, 2003). This strategy is to invite learners to make a classroom transformation by producing an alternative text which could better represent those who are left out, silenced, or marginalised in the original text (McLaughlin \& DeVoogd, 2004a).

Activities on creating alternative texts can be used in discussing various written texts, including narratives, ads, news, and visual texts including television ads, speeches, and movies (Janks et al., 2014). For example, after reading Cinderella story from a critical stance, learners can write their own alternative version to develop the narrative from a critical perspective. They can, for instance, write their own story in which Cinderella is pictured as short Asian girl rather than a slender and tall Caucasian girl to represent the silenced voice of women who do not have physical appearance implicitly considered ideal in the original story. They can even switch the gender of all of the characters in which a poor boy eventually got married to Princess Cinderella if they think the original text implicitly conveys gender inequality placing females in the lower position than males.

Another example of the use of this strategy is in discussing Hollywood movies. Teachers can invite learners to brainstorm any Hollywood action movies they have watched. Then, they can invite them to brainstorm which groups or 
communities have often been pictured as the "bad guys" in many Hollywood movies. Teachers can then ask them to produce an alternative text accommodating the silenced voices of these groups to create a more equal discourse.

The annotated sample materials in Appendix show the first strategy, problem posing, and the second one, creating alternative texts, which I implemented in an English Club meeting with English Language Education Department students of semester three being my students.

\section{Conclusion}

Rather than reading texts and accepting them as they are, teachers who engage in CL practices will be capable of becoming "open-minded, active, strategic readers who are capable of viewing text from a critical perspective" (McLaughlin \& DeVoogd, 2004, p. 56). This will lead them to realize that every day's texts are never neutral and they have been written or made from a particular perspective and for a particular purpose (Janks et al., 2014). These teachers can, in turn, facilitate learners to be able to do so as well through instructions. When learners are guided to learn how to read texts around them from a critical stance, they will eventually be able to view any texts they encounter from a critical stance "as naturally as they view it from aesthetic and efferent stances" (McLaughlin \& DeVoogd, 2004, p. 56).

Learning contexts that foster CL are commonly characterized by some contributing factors which are intertwined with each other (McLaughlin \& DeVoogd, 2004a). The first is teachers who are critically aware of the world or discourses around them. The second is students who are actively engaged. The third and fourth are motivational settings and the use of CL strategies. Finally, the fifth and the sixth are thoughtprovoking texts and a large amount of critical discussion. It is because to become critically literate, one needs a developmental process in which they do continuous practice and reflection through critical discussions triggered with thought-provoking texts (McLaughlin \& DeVoogd, 2004a).

Finally, as CL functions as a universal tool through which one can critically analyze any texts, once teachers and learners have been engaged in it, they can use it for reading any texts around them from a critical stance (Janks, 2010; Vasquez, 2010). This will eventually empower them to be agents who are critically aware of the power and silenced voices implicitly manifested in every day's discourses with the hope that they could accommodate the voices silenced to be present or to be present more equally (Janks, 2010; Lau, 2013).

\section{References}

Bean, T. W., \& Moni, K. (2003). Developing students' critical literacy: Exploring identity construction in young adult fiction. Journal of Adolescent $\mathcal{E}$ Adult Literacy, 46(8), 638-648.

Bourdieu, P. (1991). Language and Symbolic Power. In J. Thompson 
(Ed.), Language and Symbolic Power. Polity Press.

Comber, B. (2001). Negotiating Critical Literacy. National Council of Teachers of English, 6(3), 1-2.

Crookes, G. V. (2013). Critical ELT in Action: Foundations, Promises, and Praxis. Routledge.

Freire, P. (1972). Pedagogy of the Oppressed. Penguin.

Freire, P., \& Shor, I. (1987). A Pedagogy for Liberation: Dialogues on Transforming Education. MacMillan.

Janks, H. (2004, February). The access paradox. English in Australia, 139, 33-42.

Janks, H. (2010). Literacy and Power. Routledge.

Janks, H. (2017). Critical literacy and the social justice project of education. English Teaching: Practice \& Critique, 16(2), 132-144. https://doi.org/https://doi.org/10. 1108/ETPC-09-2016-0111

Janks, H., Dixon, K., Ferreira, A., Granville, S., \& Newfield, D. (2014). Doing Critical Literacy: Texts and Activities for Students and Teachers. Routledge.

Johnson, K. E. (1994). The emerging beliefs and instructional practices of preservice English as a second language teachers. Teaching $\mathcal{E}$ Teacher Education, 10(4), 439-452.

Lau, S. M. (2013). A study of critical literacy work with beginning English language learners: An integrated approach. Critical Inquiry in Language Studies, 10(1), 1-30.

https://doi.org/10.1080/15427587. 2013.753841

Luk, J. C. M., \& Lin, A. M. Y. (2006). Uncovering the sociopolitical situatedness of accents in the World Englishes paradigm. In R. Hughes (Ed.), Spoken English, TESOL and applied linguistics: Challenges for theory and practice (pp. 3-22). Palgrave Macmillan.

McLaughlin, M., \& DeVoogd, G. (2004a). Critical Literacy. Scholastic.

McLaughlin, M., \& DeVoogd, G. (2004b). Critical literacy as comprehension: Expanding reader response. Journal of Adolescent \& Adult Literacy, 48(1), 52-62.

https://doi.org/10.1598/JAAL.48.1 .5

Richards, J., \& Rodgers, T. S. (2014). Approaches and Methods in Language Teaching (Third Edit). Cambridge University Press.

Vasquez, V. (2004). Negotiating critical literacies with young children. Erlbaum.

Vasquez, V. (2010). Critical literacy isn't just for books anymore. The Reading Teacher, 63(7), 614-616. 